\title{
Eksistensi Tradisi Nyadran sebagai Penguatan Identitas Nasional di Tengah Modernisasi
}

\author{
Ravita Mega Saputri ${ }^{1}$, Alil Rinenggo ${ }^{2}$, Suharno ${ }^{3}$ \\ ${ }^{1}$ Pascasarjana Universitas Negeri Yogyakarta, ${ }^{2}$ Universitas Darul Ulum Islamic Centre \\ Sudirman GUPPI, ${ }^{3}$ Universitas Negeri Yogyakarta \\ E-mail: ${ }^{1}$ saputriravita110@gmail.com, ${ }^{2}$ rinenggoalil@gmail.com, ${ }^{3}$ suharno@uny.ac.id
}

\begin{abstract}
This study aims to determine the efforts to preserve the Nyadran tradition in Gabus Village, Ngrampal District, Sragen Regency, Central Java Province as a strengthening of national identity in Indonesia, especially in Javanese society. The research method uses a qualitative descriptive method as an approach in research. Data was collected through observation and interviews with resource persons, and documentation. The resource persons consisted of the head of the RT, the Gabus Village community, and religious leaders. Documents in the form of photos of Nyadran's activities. Qualitative data analysis through data reduction, data presentation, and drawing conclusions. The results of the study indicate that the efforts of the Nyadran tradition are by: 1) introducing the Nyadran tradition to the younger generation who are involved in the management of the implementation from the beginning to the end of the event. 2) families familiarize children from childhood in all good things. Likewise, teaching about the Nyadran tradition, which at first children only imitated when they grew up with the guidance of their parents, gave an understanding of the Nyadran tradition. 3) Customary institutions and the government work together to provide understanding and preservation related to the Nyadran tradition.
\end{abstract}

Keywords: National Identity, Modernization, Nyadran Tradition

\begin{abstract}
Abstrak
Penelitian bertujuan untuk mengetahui upaya pelestarian tradisi Nyadran di Desa Gabus, Kecamatan Ngrampal, Kabupaten Sragen, Provinsi Jawa Tengah sebagai penguatan identitas nasional di Indonesia terutama pada masyarakat Jawa. Metode penelitian menggunakan metode deskriptif kualitatif sebagai pendekatan dalam penelitian. Pengumpulan data dilakukan melalui observasi dan wawancara dengan narasumber, dan dokumentasi. Narasumber terdiri atas ketua RT, masyarakat Desa Gabus, dan tokoh agama. Dokumen berupa goto-foto kegiatan Nyadran. Analisis data secara kualitatif melalui reduksi data, penyajian data, dan pengambilan simpulan. Hasil penelitian menunjukkan bahwa upaya tradisin Nyadran dengan cara:1) memperkenalkan tradisi Nyadran pada generasi muda yang dilibatkan dalam kepengurusan pelaksanaan dari awal sampai akhir acara. 2) keluarga membiasakan anak sejak kecil dalam segala hal yang baik. Begitu pula dengan mengajarkan mengenai tradisi Nyadran yang pada awalnya anak hanya meniru setelah dewasa dengan bimbingan orang tua memberikan pemahaman tentang tradisi Nyadran. 3) lembaga adat dan pemerintah bekerja sama memberikan pemahaman dan pelestarian terkait dengan tradisi Nyadran.
\end{abstract}

Kata Kunci: Identitas Nasional, Modernisasi, Tradisi Nyadran 
CIVICS EDUCATION AND SOCIAL SCIENSE JOURNAL (CESSJ)

Volume 3 Nomor 2 Edisi Bulan Desember 2021

\section{Pendahuluan}

Indonesia merupakan negara yang mempunyai banyak keragaman suku bangsa, bahasa, ras atau etnis dan adat istiadat. Terdapat 1.331 kelompok suku bangsa dan 652 bahasa daerah (Azamella, 2019). Pluralisme budaya menekankan pentingnya masyarakat mengakui perbedaan budaya dan memberikan akses dan peluang kepada kelompok yang berbeda secara budaya untuk berkembang dalam masyarakat yang menghargai atribut dan kontribusi positif mereka (Antonia \& Perry, 1976: 120). Kemajemukan tersebut dapat memberikan dampak positif yaitu seseorang memiliki kekayaan kekhasan budhaya yang beragam. Ada juga dampak negatif dengan adanya keberagaman dapat memicu konflik antar kelompok masyarakat. Upaya untuk menghadapi pluralisme ini diperlukan sikap lebih toleran yang bertujuan untuk mencegah dan memecahkan masalah terhadap benturan budaya.

Kebudayaan di Indonesia mempunyai nilai dan makna yang berbeda-beda antar satu daerah dengan daerah lainnya. Hal ini membuat para wisatawan lokal maupun manca negara menyebut bahwa negara Indonesia identik dengan ragam budayanya. Namun budaya tersebut tidak akan indah jika tidak diapresiasikan dan dilestarikan di dalam kehidupan bermasyarakat. Apresiasi budaya sangat diperlukan agar dapat mencegah budaya lokal tidak digeser oleh arus modernisasi. Bentuk apresiasi terhadap budaya dengan melestarikan dan mengenalkan budaya lokal kepada masyarakat luas, khususnya pada generasi muda sebagai pewaris budaya. Salah satu budaya yang masih tumbuh dalam kehidupan masyarakat Jawa yakni tradisi Nyadran.

Tradisi Nyadran merupakan upacara ritual bernilai religius yang telah diwariskan turun-temurun hingga berlangsung sampai sekarang. Kehadiran ritual ini sebagai efek dari hubungan sosial yang umumnya terdapat perubahan sikap, pendekatan, dan tingkah laku publik yang diharapkan masyarakat (Wijaya, 1993). Suatu tradisi berguna untuk menunjukkan makna filosofi nilai moral yang menghubungkan orang satu dengan orang lainnya yang mengandung unsur-unsur kejiwaan yang mendalam (Effendi, 2009).

Tradisi Nyadran awalnya dilakukan oleh masyarakat Jawa sebagai pemujaan terhadap roh leluhur dan setelah kehadiran Walisongo di Jawa, maka ritual pemujaan roh bertransformasi ke dalam nilai budaya yang islami (Hasanah, 2013). Tradisi Nyadran merupakan aset budaya bagi bangsa Indonesia yang perlu dilestarikan agar keaslian dan eksistensinya tidak terkikis oleh derasnya modernisasi. Pada kenyataannya masyarakat Indonesia saat ini lebih memilih kebudayaan asing yang dianggap menarik ataupun unik. Kebudayaan lokal semakin luntur akibat kurangnya apresiasi oleh generasi muda terhadap budaya lokal.

Arus modernisasi menjadi kekuatan yang sangat dahsyat dalam mempengaruhi pola pikir manusia yang memandang budaya Barat yang diidentikkan sebagai budaya modernitas, sedangkan budaya Timur dipandang sebagai budaya tradisional atau konvensional. Dengan begitu masyarakat Timur lebih cenderung meniru gaya hidup orang Barat. Demikian, menjadikan budaya lokal terutama budaya di Indonesia mengalami pengeseran nilai akibat masuknya modernisasi yang tidak dapat terbendung. Apabila masyarakat tidak memanfaatkan modernisasi ini dengan baik, maka budaya lokal tersebut dapat hilang oleh arus 
CIVICS EDUCATION AND SOCIAL SCIENSE JOURNAL (CESSJ)

Volume 3 Nomor 2 Edisi Bulan Desember 2021

modernisasi. Adanya dampak modernisasi tersebut, masyarakat harus mampu mempertahankan nilai-nilai luhur dan budaya untuk mempertahankan identitas nasional.

Identitas tidak hanya individu, tetapi juga kolektif dan sosial. Identitas adalah perbedaan karakter dan rasa memiliki yang ditemukan dalam interaksi antar pribadi, interaksi antar kelompok dan muncul dari pandangan diri sebagai aktivitas refleksif atau identifikasi dalam hal keanggotaan khususnya grup atau peran (Stets \& Burke, 2000). Identitas nasional adalah produk dari pengembangan nasionalisme modern. Sedangkan identitas budaya sebagai manifestasi atribut sosial manusia yang merupakan media penting dan dapat mempengaruhi identitas masyarakat individu, kelompok etnis, dan identitas nasional (Han, 2010). Oleh karena itu, identitas nasional mengacu pada identitas warga negara dengan tradisi sejarah dan budaya di setiap negara yang berbeda-beda. Identitas nasional mengandung nilai-nilai moral, cita-cita, kepercayaan, kedaulatan nasional, dan sebagainya.

Tradisi Nyadran merupakan bagian dari identitas nasional terutama bagi masyarakat Jawa. Dalam tradisi Nyadran, ritual tersebut menyajikan makanan berupa tumpeng, ingkung (daging ayam) dan pisang Raja kemudian makanan tersebut dikumpulkan dan didoakan oleh tokoh agama. Tradisi Nyadran di Desa Gabus, Kecamatan Ngrampal, Kabupaten Sragen, Provinsi Jawa Tengah Indonesia dilaksanakan menjelang Ramadhan dan dilaksanakan pada saat sesudah penanaman ataupun sesudah panen padi. Tradisi Nyadran menggunakan sesaji atau makanan sebagai perlengkapan ritusnya dan diakulturasikan dengan doa-doa yang bersumber dari Al-Quran.

Penelitian relevan yang dilakukan oleh Parji (2016) menunjukkan bahwa tradisi Nyadran merupakan warisan nenek moyang yang berasal dari Jawa. Tradisi Nyadran dipengaruhi oleh budaya Hindu dan agama Islam. Tradisi Nyadran mempunyai nilai-nilai sosial-kultural meliputi nilai gotong royong, toleransi, religius, persatuan dan kesatuan, dan kerja sama. Tradisi Nyadran harus dijaga dan dilestarikan agar tradisi ini tetap eksis di tengah modernisasi. Cara menjaga dan melestarikan budaya lokal di Indonesia dapat dilakukan dengan culture experience yakni sebagai upaya pelestarian budaya dengan cara ikut serta dalam proses ritual (Sendjaja, 1994).

Berdasarkan hasil wawancara dengan tokoh agama bahwa tradisi Nyadran merupakan prosesi berdoa kepada Tuhan sebagai bentuk penghargaahn terhadap bulan Sya'ban yaitu bulan pelaporan atas amal perbuatan manusia. Oleh karena itu pelaksanaan ziarah kubur juga diartikan sebagai upaya intropeksi diri atau perenungan terhadap sikap/ atau perilaku yang telah dilakukan selama satu tahun. Sedangkan tradisi Nyadran yang dilaksanakan sesudah penanaman dan panen padi tradisi Nyadran ini merupakan wujud dari pengucapan rasa syukur atas hasil padi dan bumi sangat melimpah karena kesuburan tanah dan sumber airnya melimpah. Tradisi Nyadran ini juga mempersembahkan sesaji berupa makanan di sawah dan kemudian didoakan yang dipimpin oleh tokoh agama dan diiringi masyarakat Desa Gabus.

Mengingat maraknya budaya modern yang terus berkembang dan gaya kehidupan masyarakat semakin maju, namun nyatanya tradisi Nyadran masih tetap dilaksanakan oleh masyarakat Jawa, agar prosesi Nyadran ini tidak luntur akibat 
CIVICS EDUCATION AND SOCIAL SCIENSE JOURNAL (CESSJ)

Volume 3 Nomor 2 Edisi Bulan Desember 2021

modernisasi maka masyarakat setempat harus mampu melestarikan prosesi Nyadran dengan mengenalkan kepada masyarakat umum dan generasi muda agar tradisi ini tidak terkikis oleh arus modernisasi. Dengan mengangkat tema tradisi Nyadran peneliti ingin mengetahui upaya pelestarian tradisi Nyadran sebagai bentuk penguatan identitas nasional di Indonesia terutama pada masyarakat Jawa.

\section{Metode Penelitian}

Penelitian ini menggunakan penelitian deskriptif kualitatif. Penelitian dilaksanakan di Desa Gabus, Kecamatan Ngrampal, Kabupaten Sragen, Provinsi Jawa Tengah. Pendekatan kualitatif dilakukan untuk mengkaji perilaku dan kejadian secara alami. Penelitian dilakukan pada bulan Mei s.d bulan November 2020. Jenis penelitian deskriptif digunakan untuk menggambarkan tentang kejadian secara nyata dalam sebuah hubungan fakta-fakta dengan menggunakan kata-kata secara rinci untuk merefleksikan data dengan akurat dari perilaku manusia yang kompleks. Pendekatan kualitatif dengan jenis deskriptif dilakukan untuk mengumpulkan data secara mendalam mengenai kondisi nyata tentang upaya masyarakat dalam menjaga eksistensi tradisi Nyadran dalam menguatkan identitas nasional di tengah modernisasi.

Subjek penelitian menggunakan teknik purposive, karena diperoleh dengan cara mempertimbangkan dan memasukkan kriteria, sehingga peneliti mendapatkan informasi sebanyak mungkin dari berbagai kriteria yang telah ditemukan dalam penelitian. Subjek penelitian yakni ketua RT, masyarakat Desa Gabus, dan tokoh agama. Pengumpulan data menggunakan teknik wawancara, observasi dan dokumentasi. Keabsahan data menggunakan teknik triangulasi sumber dan teknik. Triangulasi sumber membandingkan dan mengecek data yang diperoleh dari suatu sumber yang menghasilkan data yang sama ketika sudah dibandingkan dengan sumber yang lain. Triangulasi teknik membandingkan dan mengecek data yang diperoleh melalui beberapa teknik pengumpulan data. Pada penelitian ini, penulis menggunakan triangulasi teknik untuk mengecek data yang telah diperoleh melalui hasil wawancara sama dengan data yang diperoleh dari observasi dan melalui teknik dokumentasi. Penelitian menggunakan analisis dan model interaktif dari Miles \& Huberman (1994). Proses analisis data meliputi komponen reduksi data, penyajian data, dan penarikan simpulan.

\section{Hasil dan Pembahasan \\ Hakikat Tradisi Nyadran}

Istilah Nyadran berasal dari bahasa Sansekerta "Sraddha". Kata Sraddha kemudian diubah menjadi Sadran atau Nyadran yang berarti ziarah kubur. Dalam tradisi Nyadran, masyarakat memanjatkan doa selamat. Tradisi Sraddha ini awalnya dilakukan sekitar tahun 1284 di Kerajaan Majapahit yang dulunya berarti keyakinan. Dalam melaksanakan Sraddha menggunakan pujian dan persembahan sebagai perlengkapan ritual. Tradisi ini pertama kali dilakukan oleh Ratu Tribuana Tungga Dewi sebagai Raja Majapahit pada waktu itu (Julianto, et al., 2021: 831).

Secara geografis Desa Gabus merupakan daerah yang termasuk wilayah di Kecamatan Ngrampal, Kabupaten Sragen, Provinsi Jawa Tengah Indonesia. Desa Gabus mempunyai luas wilayah 665,8550 Ha dan terdiri dari 4 dusun dan terbagi 
CIVICS EDUCATION AND SOCIAL SCIENSE JOURNAL (CESSJ)

Volume 3 Nomor 2 Edisi Bulan Desember 2021

menjadi 50 RT. Masyarakat Desa Gabus tergolong sebagai masyarakat yang menjunjung paguyuban, karena masih memegang teguh kerukunan, nilai-nilai, kebersamaan, dan gotong royong. Hal Ini sebagai bentuk solidaritas yang masih khas di lingkungan pedesaan yang bersifat tradisional. Masyarakat Desa Gabus mayoritas beragama Islam. Sebagain besar masyarakat Desa Gabus masih melestarikan tradisi dan kebudayaan Jawa. Masyarakat masih mengikuti tradisi Keraton Surakarta dan Yogyakarta. Tradisi ini mempunyai peran penting dalam menjalin hubungan kekeluargaan antar masyarakat.

Tradisi berasal dari kata tradition yang artinya menyerahkan, meneruskan turun menurun (Laksono, 2009). Tradisi yang berkembang di masyarakat melalui dua cara yakni mekanisme kemunculan secara spontan yang tidak diharapkan serta melibatkan orang banyak dan mekanisme paksaan (Piotr, 2008). Tradisi berkembang di masyarakat beranekaragam di setiap daerah yang mempunyai keunikan sendiri. Seperti halnya tradisi yang berasal dari masyarakat Jawa yang merupakan peninggalan nenek moyang. Salah satu tradisi yang tetap dipegang teguh hingga sekarang oleh masyarakat Jawa yaitu tradisi Nyadran.

Tradisi Nyadran menurut Prasetyo (2010) suatu tradisi yang dilakukan oleh masyarakat Jawa setiap menjelang puasa Ramadhan, yang dilakukan di bulan Sya 'ban (kalender Hijriyah) atau Ruwah (kalender Jawa) untuk mengucapkan rasa syukur. Secara kolektif dengan mengunjungi makam atau kuburan leluhur yang ada di suatu Desa. Tradisi Nyadran merupakan tradisi keagamaan sebagai bentuk penghormatan pada leluhur, bentuk syukur kepada Tuhan, dan agar terhindar dari penyakit (Triyoso, 2021: 21).

Berdasarkan wawancara dengan ketua RT Desa Gabus bahwa prosesi Nyadran dapat diselenggarakan sebelum menjelang Ramadhan dan dilakukan sesudah penanaman dan sesudah panen hasil bumi yaitu seperti panen padi, jagung, dan lain sebagainya secara serentak. Masyarakat Desa Gabus secara mayoritas merupakan masyarakat Muslim yang memberikan kesepakatan adanya pelestarian budaya yakni tradisi Nyadran. Bahkan pemerintah setempat juga mendukung pelaksanaan tradisi Nyadran. Selain dukungan moril, pemerintahan setempat juga memberikan dukungan materil. Berikut salah satu bukti penyelenggaraan prosesi Nyadran di Desa Gabus, Kecamatan Ngrampal, Kabupaten Sragen, Provinsi Jawa Tengah, dapat dilihat pada gambar berikut.

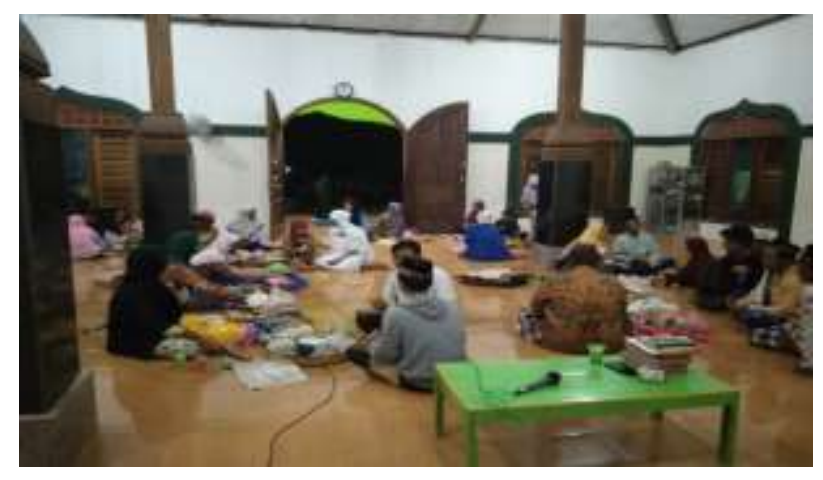

\section{Gambar 1. Prosesi Nyadran yang dilaksanakan di Masjid}


CIVICS EDUCATION AND SOCIAL SCIENSE JOURNAL (CESSJ)

Volume 3 Nomor 2 Edisi Bulan Desember 2021

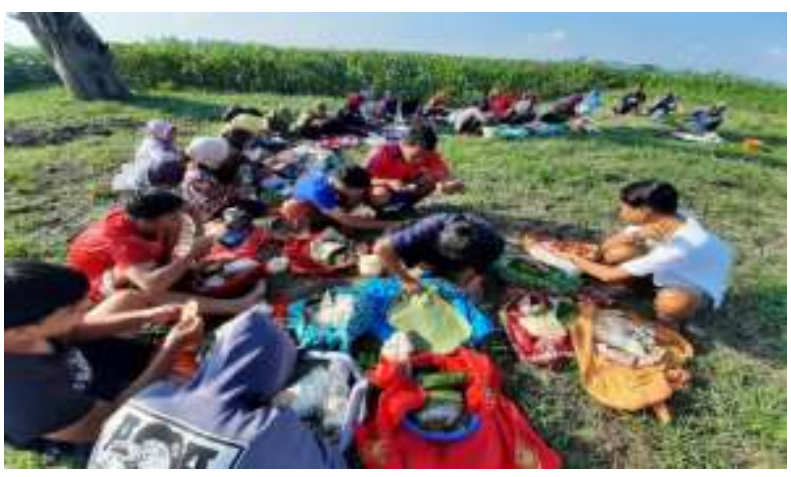

\section{Gambar 2. Prosesi Nyadran yang dilaksanakan di Sawah}

Masyarakat terlihat sangat antusias dalam melaksanakan tradisi Nyadran, baik dari kalangan anak-anak, dewasa, maupun orang tua. Semua masyarakat ikut andil dalam pelaksanaan tradisi Nyadran menjelang Ramadhan dilakukan di masjid kemudian berkunjung di makam sebagai penghormatan masyarakat kepada leluhur yang telah wafat. Tokoh agama memimpin doa bersama untuk almarhum dan almarhumah leluhur di makam. Setelah itu, melakukan ritual seperti menyiram air di atas makam leluhur, menabur bunga, dan wangi-wangian, kemudian melantunkan doa kembali. Sedangkan tradisi Nyadran yang dilakukan pada saat sesudah penanaman dan sesudah panen padi dilaksanakan di sawah dengan membacakan doa yang dipimpin oleh tokoh agama. Tradisi Nyadran tersebut samasama menyajikan makanan berupa tumpeng, ingkung (daging ayam) dan pisang Raja kemudian makanan tersebut dikumpulkan dan didoakan oleh tokoh agama.

Berdasarkan hasil wawancara dengan masyarakat, tujuan dilaksanakan tradisi Nyadran oleh masyarakat Desa Gabus (Kecamatan Ngrampal, Kabupaten Sragen, Provinsi Jawa Tengah) pada waktu sesudah penanaman dan sesudah panen yaitu untuk mengingat para leluhur yang telah meninggal dunia, jasa para leluhur dalam pembukaan lahan (babat alas) yang sampai saat ini digunakan oleh masyarakat sebagai tempat tinggal dan mencari kehidupan. Sedangkan tujuan tradisi Nyadran yang dilakukan menjelang bulan Ramadhan yaitu untuk mendoakan para arwah leluhur yang telah kembali di sisi Allah Swt. Selain tujuan utama tradisi Nyadran dijadikan sarana untuk mengingatkan umat manusia bahwa suatu saat nanti akan mengalami kematian. Melalui tradisi Nyadran mampu meningkatkan rasa persaudaraan di kalangan masyarakat karena hampir semua masyarakat membaur dalam acara Nyadran.

Masuknya modernisasi dalam kehidupan manusia telah menggeser tradisi yang diwariskan oleh nenek moyang. Ada juga masyarakat menganggap bahwa tradisi Nyadran hanya akan menambah pemborosan sehingga masyarakat meninggalkan tradisi tersebut. Permasalahan ini timbul akibat modernisasi yang telah masuk di lingkungan masyarakat yang dapat mengubah pandangan dan cara 
CIVICS EDUCATION AND SOCIAL SCIENSE JOURNAL (CESSJ)

Volume 3 Nomor 2 Edisi Bulan Desember 2021

berpikir yang lebih modern. Apabila tradisi ini tidak mendapat perhatian, maka lama-lama akan hilang sehingga diperlukan suatu usaha yang dapat menjaga tradisi Nyadran di tengah arus modernisasi. Tradisi ini patut dipertahankan sebab selain meningkatkan rasa persaudaraan di kalangan masyarakat, juga sebagai identitas nasional agar masyarakat di luar daerah ataupun negara mengetahui adanya tradisi Nyadran ini.

\section{Identitas Nasional dalam Perspektif Modernisasi}

Identitas nasional merupakan produk dari pengembangan nasionalisme modern. Sejak Revolusi Perancis, nasionalisme modern bukan hanya ideologi tetapi juga gerakan politik dan sosial yang didasarkan pada ideologi (Zheng, 2004). Identitas nasional dalam perspektif modernisasi secara sosial dibangun dan dinegosiasikan dalam diri individu. Identitas nasional hanyalah satu dari beberapa bentuk identitas kolektif. Identitas nasional tidak hanya muncul berdasarkan kesadaran akan kesatuan latar belakang budaya, etnis, agama, atau kelompok sosial, tetapi lebih merupakan strategi produk sosial, budaya, politik untuk membangun, dan memproduksi identitas sebagai negasi identitas yang diberlakukan oleh kekuatan kolonial (Anderson, 2006).

Identitas nasional dipersatukan dari banyak elemen, seperti budaya, warisan, agama, hukum dan nilai-nilai. Identitas nasional menurut Smith (1999) melibatkan komunitas politik, sejarah, wilayah, patria, kewarganegaraan, nilai-nilai dan tradisi bersama. Identitas nasional menjadi seperangkat makna yang dimiliki oleh budaya tertentu yang membedakannya dari budaya lain (Keillor dan Hult, 1999). Peran mitos mengenai nilai-nilai, tradisi dan simbol sebagai pembeda yang kuat dan pengingat budaya unik dan nasib komunitas etnis, hingga analisisnya tentang identitas nasional (Guibernau, 2004).

Keillor dan Hult (1999) menjelaskan pentingnya budaya, etnis dan warisan dalam membentuk gagasan tentang identitas nasional yang digambarkan ada empat komponen dasar kerangka identitas nasional, yaitu homogenitas budaya, struktur kepercayaan, warisan nasional, dan etnosentrisme. Homogenitas budaya digambarkan sebagai jumlah subkultur dalam seperangkat batasan nasional, struktur kepercayaan didefinisikan sebagai peran yang dimainkan agama dalam memfasilitasi partisipasi budaya dan solidaritas, sementara komponen warisan nasional mencerminkan rasa budaya yang diberikan akan sejarah unik, dan etnosentrisme pada umumnya dianggap sebagai sesuatu yang membuat masyarakat, mengevaluasi dan atribusi budaya menggunakan perspektif budaya sebagai kriteria garis dasar. Definisi tersebut menjelaskan pentingnya budaya, etnis dan warisan dalam membentuk gagasan tentang identitas nasional dan konsep identitas kolektif menjadi penting bagi manusia, terutama identitas nasional sebagai legitimasi keberadaan dalam sistem sosial yang diakui oleh hukum. Identitas nasional didefinisikan sebagai sejauh mana budaya yang diberikan mengenali dan mengidentifikasi serangkaian elemen fokus yang membedakannya dari budaya lain dengan menunjukkan kompleksitas dan variasi yang lebih besar dalam institusi dari aspek-aspek tersebut dari pada yang lain (Cui dan Adams, 2002).

Modernisasi yang didefinisikan oleh Smith (1981) sebagai pengiring sosial dari industrialisasi, pada akhirnya akan melemahkan pentingnya karakteristik 
CIVICS EDUCATION AND SOCIAL SCIENSE JOURNAL (CESSJ)

Volume 3 Nomor 2 Edisi Bulan Desember 2021

budaya seperti agama, bahasa, dan ras. Fakta bahwa modernisasi tampaknya telah menyebabkan proliferasi diferensiasi etnis. Faktor-faktor dalam kehidupan sosial modern yang mempengaruhi pembentukan identitas etnis, terutama dalam kasuskasus di mana identitas etnis baru muncul dari identitas lama yang sebelumnya dimiliki. Proliferasi diferensiasi etnis yang terjadi di seluruh dunia terkait dengan dua perubahan penting yang dibawa oleh proses modernisasi: Pertama, peningkatan kontak dan kesadaran di antara kelompok-kelompok sosial. Kedua, demokratisasi yang telah menghasilkan penghapusan banyak hambatan yang sebelumnya digunakan untuk stratifikasi kelompok. Faktor-faktor tersebut ditandai dengan persepsi ketidaksetaraan yang berfungsi sebagai katalis untuk pengembangan kesadaran kelompok etnis, yang mengarahkan pada identitas nasional sebagai bentuk identitas etnis yang lebih mengakar, di mana anggota kelompok etnis percaya bahwa kelompok etnis harus bertanggung jawab atas negara berdaulat atau bangsa.

Berdasarkan hasil wawancara dengan masyarakat Desa Gabus bahwa masyarakat masih memegang teguh adat istiadat setempat. Solidaritas antar masyarakat masih dijunjung tinggi dalam menguatkan budaya lokal seperti tradisi Nyadran. Solidaritas masyarakat dibentuk karena adanya sistem nilai kebersamaan antar masyarakat lain yang secara historis dibangun melalui tradisi (Durkheim, 1964). Nilai-nilai yang terdapat dalam tradisi Nyadran yaitu kerukunan, gotong royong, dan nilai religius (Lidya, 2018).

Tradisi Nyadran mempunyai nilai karakter moral secara vertikal maupun secara horizontal. Nilai moral secara vertikal memunculkan hubungan yang harus dijaga spiritual dan harmonis antar manusia dengan Tuhan sebagai wujud manusia atas rahmat-Nya. Sedangkan nilai moral horizontal menunjukkan hubungan positif antar sesama manusia, manusia dengan hewan, dan manusia dengan lingkungan alam (Amin, 2017). Nilai-nilai yang harus ditanamkan dalam tradisi Nyadran meliputi nilai musyawarah, nilai peduli terhadap lingkungan, nilai komunikatif, nilai harmonis, nilai upacara adat, dan nilai religius. Nilai-nilai tersebut memperkuat integrasi bangsa melalui pelaksanaan tahapan prosesi Nyadran. Budaya lokal sebagai aset bangsa Indonesia harus memperoleh atensi khususnya di era modernisasi, sebab budaya merupakan bagian yang penting untuk bangsa Indonesia yang tidak hanya sebagai warisan ataupun adat istiadat masyarakat Indonesia yang hanya dirayakan pada saat peringatan tradisi tersebut.

Nilai-nilai budaya yang berkembang di masyarakat mencerminkan identitas nasional. Mayoritas identitas nasional diperoleh berdasarkan tempat seseorang itu dilahirkan dan dibesarkan oleh keluarganya. Pentingnya pencegahan dalam mengatasi dampak buruk dari modernisasi dengan upaya menguatkan nilai-nilai tradisional dan lokal yang menjadi identitas (Keller, 2006). Apabila masyarakat mampu memegang teguh nilai-nilai tersebut maka identitas nasional bangsa tidak akan terkikis oleh adanya modernisasi. Seperti penelitian yang dilakukan oleh Maeyulisari (2020) bahwa pelestarian tradisi Nyadran sebagai sarana untuk mempererat kerukunan antar umat beragama sehingga tetap eksis di era modernisasi.

Apabila dianalisis dari pembagian identitas nasional (Hendrizal, 2020: 5), tradisi Nyadran termasuk identitas religiusitas dan identitas sosio-kultural. Hal 
CIVICS EDUCATION AND SOCIAL SCIENSE JOURNAL (CESSJ)

Volume 3 Nomor 2 Edisi Bulan Desember 2021

tersebut dapat dilihat dari keyakinan, ritual, dan doa yang dipanjatkan masyarakat. Sedangkan dari aspek identintas sosio-kultural dapat dilihat dari warisan budaya dari leluhur yang mencerminkan sikap gotong royong, kerukunan, dan kebersamaan. Identitas nasional dan kesukuan penting untuk dipelajari secara komprehensif agar tercipta harmonisasi di tengah pluralisme dalam kehidupan masyarakat dan negara (Retnasari \& Hidayah, 2019: 331). Revitalisasi nilai budaya lokal sangat penting dilakukan untuk mempertegas identitas nasional. Nilai budaya merupakan aset bangsa yang harus digali, dipelihara, dan diamalkan di lingkungan masyarakat dan bangsa (Brata, 2017: 7).

\section{Upaya Pelestarian Tradisi Nyadran di Tengah Modernisasi}

Perjuangan untuk mempertahankan identitas budaya dalam menghadapi pembangunan datang ke garis depan debat internasional pada 1960-an selama dekolonisasi. Model-model pembangunan pada saat itu menekankan modernisasi melalui industrialisasi dan urbanisasi. Model-model ini mengancam budaya yang mapan dari populasi yang beragam dan ketika orang mulai menemukan kebebasan politik, mereka juga mulai menantang homogenisasi, atau "Westernisasi" dari budaya (UNESCO, 2003a). Sebagai tanggapan, masyarakat internasional mulai memasukkan perlindungan dan pelestarian budaya ke dalam model pembangunan, mengakui pentingnya identitas budaya untuk pemeliharaan masyarakat dan menemukan cara untuk menggunakan budaya dalam meningkatkan proses pembangunan.

Arus modernisasi dapat membawa pengaruh positif maupun negatif. Terlihat bahwa arus modernisasi terdapat suatu kebebasan antara hubungan bangsa yang membawa kebudayaan asing secara perlahan menggeser kebudayaan lokal bangsa Indonesia. Tentu hal ini harus menjadi perhatian terutama bagi generasi muda sebab para generasi muda lebih cenderung meniru budaya barat karena budaya barat sangat menyimpang dari karakter dan sifat beradat dan beradab yang dimiliki bangsa Indonesia. Bangsa Indonesia memiliki banyak keragaman sehingga bersifat multikultural yang dianggap sebagai kepercayaan bahwa kelompok etnik atau budaya dapat hidup berdampingan secara rukun dan damai. Multikultural juga merupakan formasi sosial bagi identitas yang beragam sekaligus menghubungkan ruang untuk sebuah integrasi (Sparingga, 2003).

Berdasarkan hasil wawancara dengan tokoh agama menjelaskan bahwa upaya masyarakat Desa Gabus dalam menyikapi pergeseran tradisi Nyadran akibat modernisasi dengan menjaga keberadaan tradisi agar tidak hilang dengan perkembangnya zaman. Usaha yang dilakukan agar tradisi Nyadran tidak hilang. Pertama, memperkenalkan tradisi Nyadran pada generasi muda yang dilibatkan dalam kepengurusan pelaksanaan dari awal sampai akhir acara. Dengan melibatkan generasi muda diharapkan mampu memupuk rasa bangga dan menghargai budaya, sehingga akan timbul kemauan untuk melestarikan. Kedua, keluarga membiasakan anak sejak kecil dalam segala hal yang baik. Begitu pula dengan mengajarkan mengenai tradisi Nyadran yang pada awalnya anak hanya meniru setelah dewasa dengan bimbingan orang tua memberikan pemahaman tentang tradisi Nyadran. Ketiga, lembaga adat dan pemerintah bekerja sama memberikan pemahaman terkait dengan tradisi Nyadran. Sejalan dengan penelitian Pratiwi (2019) bahwa 
CIVICS EDUCATION AND SOCIAL SCIENSE JOURNAL (CESSJ)

Volume 3 Nomor 2 Edisi Bulan Desember 2021

pelestarian tradisi Nyadran dilakukan oleh beberapa pihak yaitu masyarakat, pemerintah desa, dan pemerintah Kabupaten Lamongan (menetapkan Desa Balun sebagai Desa Wisata yang berbasis religi dan ziarah). Seperti halnya pendapat (Sendjaja, 1994) tentang menjaga atau melestarikan budaya lokal yaitu dengan culture experience, melestarikan budaya dengan cara terjun langsung dan culture knowledge, serta melestarikan budaya dengan cara membuat pusat informasi mengenai kebudayaan.

Upaya melestarikan budaya untuk mempertahhankan nilai-nilai seni budaya, nilai tradisional dengan mewujudkan secara luwes, dinamis, selektif, dan mampu beradaptasi dengan situasi dan kondisi yang selalu berubah dan berkembang. Dalam upaya melestarikan tradisi Nyadran tersebut berkaitan erat dengan teori Fungsionalisme yang dikembangkan oleh Bronisslaw Malinowski, seperti diketahui bahwa tradisi Nyadran yang ada di Desa Gabus memiliki fungsi yang dipertahankan hingga sekarang. Malinowski (1944) membedakan tiga fungsi sosial. Pertama, mengenai pengaruh atau efek terhadap adat. Tingkah laku manusia dan pranata sosial yang lain dalam masyarakat. Kedua, pengaruh terhadap kebutuhan suatu adat yang dikonsepsikan oleh masyarakat. Ketiga, pengaruh terhadap kebutuhan mutlak dari sistem sosial.

Malinowski (1944) menegaskan setiap kebudayaan yang ada memiliki fungsi. Dari segi psikologis, tradisi Nyadran di Desa Gabus sebagai ajang silaturahmi yang dimanfaatkan sebagai pengikat rasa persaudaraan yang ada dalam kehidupan masyarakat yang tetap terjaga. Sesuai dengan penelitian dari Soniatin (2021: 197) bahwa tradisi Nyadran memiliki salah satu fungsi sosial-budaya yaitu mempererat silaturahmi, pewarisan kebudayaan, dan interaksi sosial dalam masyarakat. Hal ini juga diperkuat oleh Arifah (2021: 80) bahwa tradisi Nyadran untuk menyambung silaturahmi agar tercipta kerukunan dan kedamaian. Dari segi biologis dapat diidentifikasi melalui hidangan makanan yang telah disiapkan untuk dibagikan kepada masyarakat.

Berbicara teori fungsionalisme di dalamnya terdapat suatu struktur sosial dan organisasi sosial. Struktur sosial merupakan para pelaku yang menjalankan peranannya, sedangkan organisasi sosial ialah peran yang dimainkan oleh individu dengan orang lain. Dengan demikian dapat diidentifikasi bahwa dalam tradisi Nyadran, tokoh agama menempati struktur sosial yang tinggi dalam masyarakat, karena tokoh agama sebagai pemimpin yang memiliki peran sentral dalam terhadap pelaksanaan tradisi Nyadran sehingga tokoh agama tersebut harus memiliki kesabaran, keuletan, pengalaman dan kecakapan sehingga tercapai visi dan misi yang ada dalam peraturan demi kemajuan masyarakat.

Dengan adanya modernisasi dalam kehidupan masyarakat terlihat di berbagai bidang juga terdampak modernisasi ini baik dari segi ekonomi, transportasi dan penyebaran informasi yang mudah didapat. Adanya modernisasi selain memberikan dampak positif semua mudah didapatkan, juga memberikan dampak negatif, sebagian besar masyarakat menganggap bahwa gaya hidup orang Barat adalah gaya hidup modern yang terkenal dengan istilah westernisasi. Selain sikap westernisasi, modernisasi mengakibatkan sikap sekularisme berupa suatu pandangan mengenai seseorang yang menganggap bahwa kehidupan dunia merupakan kehidupan paling penting dari pada akhirat. Modernisasi ini juga 
CIVICS EDUCATION AND SOCIAL SCIENSE JOURNAL (CESSJ)

Volume 3 Nomor 2 Edisi Bulan Desember 2021

mengancam berbagai kebudayaan masyarakat yang telah ada sejak zaman dahulu. Namun di sisi lain, tradisi dapat dijadikan benteng atau tameng untuk menghadapi arus modernisasi sehingga identitas nasional akan tetap eksis dalam perkembangan zaman (Kusuma, 2021: 166). Seperti tradisi Nyadran yang pada saat ini masih dilaksanakan oleh sebagian besar masyarakat Jawa terutama di Desa Gabus, Kecamatan Ngrampal, Kabupaten Sragen, Provinsi Jawa Tengah.

\section{Simpulan}

Berdasarkan hasil penelitian dan pembahasan dapat disimpulkan Upaya untuk melestarikan tradisi Nyadran yaitu pertama, memperkenalkan tradisi Nyadran pada generasi muda yang dilibatkan dalam kepengurusan pelaksanaan dari awal sampai akhir acara. Kedua, keluarga membiasakan anak sejak kecil dalam segala hal yang baik. Begitu pula dengan mengajarkan mengenai tradisi Nyadran yang pada awalnya anak hanya meniru setelah dewasa dengan bimbingan orang tua memberikan pemahaman tentang tradisi Nyadran. Ketiga, lembaga adat dan pemerintah bekerja sama memberikan pemahaman dan pelestarian terkait dengan tradisi Nyadran. Tradisi Nyadran di Desa Gabus dilakukan pada saat sesudah penanaman dan setelah panen padi, prosesi ini dilakukan di sawah. Sedangkan pelaksanaan tradisi Nyadran menjelang bulan Ramadhan dilakukan di makam. Tradisi Nyadran tersebut sama-sama menyajikan makanan berupa tumpeng, ingkung (daging ayam) dan pisang Raja kemudian makanan tersebut dikumpulkan dan didoakan oleh tokoh agama.

\section{Referensi}

Arifah, D. N. (2021). Relasi Pendidikan Islam dan Budaya Lokal: Studi Tradisi Sadranan. ASNA: Jurnal Kependidikan Islam dan Keagamaan, 3(1), 72-82.

Anderson, B. (2006). Imagined Communities: Reflections on the Origin and Spread of Nationalism. New York, USA: Verso.

Antonia, P., \& Perry W. (1976). Social work in a Culturally Pluralistic Society: an alternate Paradigm in Cross-cultural Perspectives, in Social Work Practice and Education. Ed Marta Sotomayor. Houston, Texas, University of Houston.

Azanella, L. A., dkk. (2019). Cek Fakta: Jokowi Sebut Ada 714 Suku dan 1.001 Bahasa di Indonesiar from https://nasional.kompas.com/read/2019/03/30/21441421/cek-fakta-jokowisebut-ada-714-suku-dan-1001-bahasa-di-indonesia

Brata, I. B. (2017). Menyama Braya: Representasi Kesadaran Kolektif Lokal Memperkuat Identitas Nasional. Seminar Nasional dan Kongres Asosiasi Pendidik dan Peneliti Sejarah (APPS) Se-Indonesia Tahun 2017 pada tanggal 13-15 Juli 2017 di Gedung Digital Library Universitas Negeri Medan.

Effendi, O. U. (2009). Komunikasi Teori dan Praktik. Bandung: PT. Remaja Rosda Karya. 
CIVICS EDUCATION AND SOCIAL SCIENSE JOURNAL (CESSJ)

Volume 3 Nomor 2 Edisi Bulan Desember 2021

Erikson, E. H. (1994). Identity and the life cycle. New York: W. W. Norton \& Company Inc.

Cui, C. C., \& Adams, E. I. (2002). National identity and NATID: An assessment in Yemen. International Marketing Review, 19(6), 637-662. https://doi.org/10.1108/02651330210451953

Durkheim, E. (1964). The Division of Labour in Society, translated by George Simpson. New York: Free Press.

Guibernau, M. (2004). Anthony D. Smith on Nations and National Identity: a Critical Assessment. Nations and Nationalism, 10(1/2), 125-141. https://doi.org/10.1111/j.1354-5078.2004.00159.x

Han, Z. (2010). On National Identity, Ethnic Identity and Cultural Identity an Analysis and Reflection based on Historical Philosophy. Journal of Beijing Normal University (Social Science Edition), 1, 106-113.

Hasanah, H. (2013). Menakar Implikasi Psiko-sosio-religius Perayaan Imlek Etnis Thionghoa Lasem Rembang. Jurnal Penelitian Islam Empirik, 6(1), 88-106. DOI: http://dx.doi.org/10.21043/jupe.v8i1.1338

Hendrizal. (2020). Mengulas Identitas Nasional Bangsa Indonesia Terkini. Jurnal PPKn dan Hukum, 15(1), 1-21.

Julianto, T., et al. (2021). Local-Social Wisdom in the Nyadran Tradition as a Means of Gathering. Budapest International Research and Critics in Linguistics and Education (BirLE) Journal, 4(2), 830-836.

Keillor, B. D., \& Tomas M. Hult, G. (1999). A Five- country Study of National Identity. International Marketing Review, 16(1), 65-84. https://www.emerald.com/insight/content/doi/10.1108/02651330210451953 /full/html

Kusuma, F. S. D. (2021). Rasionalitas Tradisi Nyadran Masa Pandemi Masyarakat Kabupaten Sidoarjo. Inovatif, 7(2), 156-169.

Laksono, P. M. (2009). Tradisi: dalam Struktur Masyarakat Jawa, Kerajaan dan Pedesaan. Yogyakarta: Kepel Press.

Lidya, A. (2018). Konstruksi Sosial atas Tradisi Nyadran di Desa Ampeldento Kecamatan Karangploso Kabupaten Malang. PIPS, Universitas Negeri Malang.

Maeyulisari, M. (2020). Tradisi Nyadran sebagai Perekat Kerukunan Antar Umat Beragama di Dusun Kalitanjung Desa Tambaknegara Kecamatan Rawalo Kabupaten Banyumas. Skripsi, IAIN Purwokerto.

Malinowski, B. (1944). A Scientific Theory of Culture and Other Essays. Chapen Hill: The University of North Corolina Press. 
CIVICS EDUCATION AND SOCIAL SCIENSE JOURNAL (CESSJ)

Volume 3 Nomor 2 Edisi Bulan Desember 2021

Miles, M. B., and Huberman, M. (1994). An Expanded Sourcebook: Qualitative Data Analysis. London: Sage Publications.

Parji. (2016). Socio-Cultural Values of Nyadran Traditional Ceremony in Tawun, Ngawi, East Java, Indonesia. Sosio Humanika Jurnal Pendidikan Sains Sosial dan Kemanusian, 9(2), 287-296. www.mindamasjournals.com/index.php/sosiohumanika.

Prasetyo, Y. E. (2010). Mengenal Tradisi Bangsa. Yogyakarta: PT. Insist Press.

Pratiwi, A. A. (2019). Tradisi Nyadran sebagai Perwujudan Toleransi Antar Umat Beragama di Desa Balun, Kecamatan Turi, Kabupaten Lamongan. Skripsi, Universitas Negeri Malang.

Piotr, S. (2008). Sosiologi Perubahan Sosial. Yogyakarta: Prenanda Media Group. Retnasari, L., \& Hidayah, Y. (2019). Tinjauan Identitas Nasional dan Identitas Kesukuan pada Mahasiswa PGSD UAD Yogyakarta (Studi Kasus Mahasiswa Luar Jawa di PGSD UAD). Jurnal Muslim Heritage, 4(2), 317-334.

Sendjaja. S. D. (1994). Teori Komunikasi. Jakarta. Universitas Terbuka.

Smith, A. D. (1981). The Ethnic Revival. Cambridge, UK: Cambridge University Press.

Smith, A. D. (1991). National Identity. Reno, USA: University of Nevada Press.

Soniatin, Y. (2021). Makna dan Fungsi Budaya Tradisi Nyadran dalam Kearifan Lokal Masyarakat Dusun Sawen, Desa Sendangrejo, Kecamatan Ngimbang, Kabupaten Lamongan. Humanis, 3(2), 193-199. http://www.ejurnal.unisda.ac.id/index.php/Humanis/article/view/2486

Sparringa, D. T. (2003). Multikulturalisme dan Multi Perspektif di Indonesia. Surabaya: Forum Rektor Simpul Jawa Timur.

Stets, J. E., \& Burke, P. J. (2000). Identity Theory and Social Identity Theory. Social Psychology Quarterly, 63(3), 224-237. doi:10.2307/2695870.

Triyoso, J. D. (2021). Makna dan Fungsi Tradisi Upacara Nyadran di Dusun Ngadiboyo, Desa Ngadiboyo, Kecamatan Rejoso, Kabupaten Nganjuk (Tintingan Folklor).

UNESCO. (2003a). A Short History of UNESCO's Culture and Development Agenda. http://unesco.org/culture/development. United Nations.

Widjaja, A.W. (1993). Komunikasi dan Hubungan Masyarakat. Jakarta: Bumi Aksara.

Zheng, Y. N. (2004). China should Build National Identity. Global Times (pp. 816). Retrieved from http://www. people.com.cn/GB/paper68/12730/1143827.html 